\title{
Small Medium Enterprises' Resources and the Development of Innovation in Malaysia
}

\author{
Lily Julienti Abu Bakar and Hartini Ahmad \\ College of Business, Universiti Utara Malaysia, Malaysia
}

\begin{abstract}
More recent research has shifted attention from tangible to intangible resources as it perceived to be more important from a strategic point of view, since they bring together more frequently the requirements necessary for producing sustainable advantage: to be valuable, rare and difficult to imitate and replace by competitors (Barney 1991; Hitt et al. 2001). In view of the fact that there has been a dramatic increase in Malaysia SMEs development, this research reviews the SME resources and its contribution to innovation development. In the context of Malaysia manufacturing companies, reputational resources have been found given the highest impact on the product innovation performance compared to other factors. Survey was distributed randomly to the business owners and managers who work in various sizes of manufacturing firms. The response rate was $48 \%$ resulted from the personally administered questionnaire are considered highly favorable.
\end{abstract}

Keywords: Small Medium Enterprise (SME), Innovation, SME Resources, Innovation Performance.

\section{Introduction}

The governments of most developed economies including Malaysia see SMEs as the well-spring of economic growth and job and wealth creation. In Malaysia, Small and Medium Industries Development Corporation (SMIDEC) is responsible to formulate policy and strategy for SMEs. SMIDEC has been renamed as SME Corporation and fully operated on $2^{\text {nd }}$ January 2009 to widen it scope as a central coordinating agency for Malaysia SME (BERNAMA 2008). In order to formulate broad policies and strategies, and at the same time oversee and guide overall SMEs development, The National SME Development Council (NSDC) has been established in June 2004 as the highest policy-making body to chart the direction and strategies for Malaysia SMEs, whereby Bank Negara Malaysia (BNM) is responsible as the secretariat for the council (BNM 2005).

Malaysia SMEs have to face several challenges especially in the light of changing global market. These include the ability to compete globally, move up the value chain (UNDP 2007), as the value chain model has been extensively used by researchers to map the linkages and networks at the firm and industry level and to analyze where value resides at these two levels (Lunati et al. 2004). The SMI Association of Malaysia national president Chua Tiam Wee said Malaysian SMEs could no longer depend on being suppliers or original equipment manufacturers (OEM) to the bigger companies (Kam 2008). They 
are encourage to emphasize on product innovation, branding and new technologies to enhance their competitiveness in the global marketplace.

The present study is considered significant since the government's goal in Ninth Malaysia Plan 2006-2010 is to encourage new ideas using new strategy, technology and modern processes to enhance the business innovation in Malaysia. The overriding research questions for this study are "how do the SME resources influence the PIP"? Furthermore, in terms of the contribution to the knowledge, EO has been recognized as one of the SME's intangible resources (human/intellectual resource), as a determinant for SME's PIP.
Moreover, EO has a predictive value on growth and is identified as essential in growth oriented small firms (Ferreira et al. 2007). Entrepreneurial SMEs seem to have resources and develop more capabilities and take advantage in the search of competences. The current study is hoped to contribute to a perspective of the "entrepreneurial push" element as the driving force of strategic importance particularly in Malaysia SMEs.

\section{SMEs in Malaysia}

The Malaysia SME adopts the definition of National SMEs Development Corporation (2006) which currently classifies SMEs as follows:

Table 1: SME Definitions in Terms of Annual Sales Turnover

\begin{tabular}{|l|l|l|l|}
\hline \multicolumn{1}{|c|}{ Size } & \multicolumn{1}{|c|}{$\begin{array}{c}\text { Primary } \\
\text { Agriculture }\end{array}$} & $\begin{array}{c}\text { Manufacturing } \\
\text { (including Agro-Based) } \\
\text { and Manufacturing } \\
\text { Related Services }\end{array}$ & $\begin{array}{l}\text { Services Sector } \\
\text { (including Information } \\
\text { Communica-tions } \\
\text { Technology (ICT)) }\end{array}$ \\
\hline Small & $\begin{array}{l}\text { Between } \\
\text { RM200,000 and less } \\
\text { than RM1 million }\end{array}$ & $\begin{array}{l}\text { Between RM250,000 and } \\
\text { less than RM10 million }\end{array}$ & $\begin{array}{l}\text { Between RM200,000 and } \\
\text { less than RM1 million }\end{array}$ \\
\hline Medi-um & $\begin{array}{l}\text { Between RM1 } \\
\text { million and RM5 } \\
\text { million }\end{array}$ & $\begin{array}{l}\text { Between RM10 million and } \\
\text { RM25 million }\end{array}$ & $\begin{array}{l}\text { Between RM1 million } \\
\text { and RM5 million }\end{array}$ \\
\hline SME & $\begin{array}{l}\text { Not exceeding RM5 } \\
\text { million }\end{array}$ & $\begin{array}{l}\text { Not exceeding RM25 } \\
\text { million }\end{array}$ & $\begin{array}{l}\text { Not exceeding RM5 } \\
\text { million }\end{array}$ \\
\hline
\end{tabular}

Table 2: SME Definitions in Terms of Full Time Employees

\begin{tabular}{|l|l|l|l|}
\hline \multicolumn{1}{|c|}{ Size } & \multicolumn{1}{|c|}{$\begin{array}{c}\text { Primary } \\
\text { Agriculture }\end{array}$} & $\begin{array}{l}\text { Manufacturing } \\
\text { (including Agro-Based) } \\
\text { and Manufac- } \\
\text { turing Related Services }\end{array}$ & $\begin{array}{l}\text { Services Sector (including } \\
\text { Information Communications } \\
\text { Technology (ICT)) }\end{array}$ \\
\hline Small & $\begin{array}{l}\text { Between 5 and } \\
19 \text { employees }\end{array}$ & $\begin{array}{l}\text { Between 5 and 50 } \\
\text { employees }\end{array}$ & Between 5 and 19 employees \\
\hline Medi-um & $\begin{array}{l}\text { Between 20 } \\
\text { and } \\
\text { employees }\end{array}$ & $\begin{array}{l}\text { Between 51 and 150 } \\
\text { employees }\end{array}$ & Between 20 and 50 employees \\
\hline SME & $\begin{array}{l}\text { Not exceeding } \\
50 \text { employees }\end{array}$ & $\begin{array}{l}\text { Not exceeding 150 } \\
\text { employees }\end{array}$ & Not exceeding 50 employees \\
\hline
\end{tabular}

The 2005 Census of Establishment and Enterprises indicates that $99 \%$ of 519,000 business establishments in Malaysia are SMEs with total employment accounted more than 3 million workers (UNDP 2007). In addition, as reported in the Malaysia
SME Annual Report 2006, SMEs accounted for $99.2 \%$ of total business but the SME sector only contributed $32 \%$ of real gross domestic product (GDP) (SMIBD 2008). It shows that SMEs having vast opportunities to contribute in the domestic economy. For 
a record, as updated by Malaysian Industrial Development Authority (MIDA) as at 11 1 th $^{\text {May }} 2007$ (MIDA 2007), there were several SMEs industries that have been classified as follows:

- Electrical and Electronic Industry

- Engineering Supporting Industries

- Food Processing Industry

- Life Science Industry

- Machinery and Equipment Industry

- Petrochemical and Polymer Industry

- Rubber Products Industry

- Textiles and Apparel Industry

- Transport Equipment Industry

- Basic Metal Products Industry

- Wood-based Industry

The majority of manufacturing companies are located in the central parts of Malaysia and around the country's major industrial regions (Saleh et al. 2006). According to MIDA's Director General, 75 percent of improved projects by MIDA between 2002 and 2007 in the manufacturing sector have been implemented (Damodaran 2008). Industry like plastic manufacturing (generally categorized as petrochemical and polymer industry) is expected to grow up to 12 percent next year as new capacity come on-stream (NST 2008).

According to the research evaluation made by Saleh and Ndubisi (2006), Malaysia SME faced many domestic and global challenges in achieving economies of scale and competing internationally. Among the challenges are:

- Low level of technological capabilities

- Limited skilled human capital resources

- Low level of technology and ICT penetration

- Low level of R\&D

- A substantial orientation towards domestic markets

- A high level of international competition

- A high level of bureaucracy in government agencies

- Difficulties in accessing internal sourcing of funds

Despite having diverse challenges, Malaysia SMEs also having various strengths and weaknesses (Table 3) as highlighted by Hashim (2004):

\section{Table 3: Malaysia SMEs Strengths and Weaknesses}

\begin{tabular}{|c|c|}
\hline The Strengths of SMEs & The Weaknesses of SMEs \\
\hline $\begin{array}{l}\text { 1. Economic output } \\
\text { 2. Provide employment opportunities } \\
\text { 3. Regional income generation } \\
\text { 4. Savings } \\
\text { 5. Training } \\
\text { 6. Stimulate competition } \\
\text { 7. Aid to large firms } \\
\text { 8. Encourage innovation and } \\
\text { flexibility } \\
\text { 9. As a seed-bed from which large } \\
\text { firms grow } \\
\text { 10. Breeding ground for new venture } \\
\text { and entrepreneurs }\end{array}$ & $\begin{array}{l}\text { 1. Lack of capital and credit facilities } \\
\text { 2. Shortage of skilled workers } \\
\text { 3. Shortage of raw materials } \\
\text { 4. Inadequate infrastructure } \\
\text { 5. Lack of managerial and technical } \\
\text { expertise } \\
\text { 6. Marketing constraints and knowledge } \\
\text { 7. Limited application of new technology } \\
1 .\end{array}$ \\
\hline
\end{tabular}

The importance of SMEs to Malaysian economies also has been widely recognized. For example, in the Ninth Malaysia Plan 2006-2010, the promotion of technology and innovation driven in SMEs has been given increased priority since SMEs in Malaysia are contributing significantly to the growth and value added of the services and manufacturing sectors which given opportunities to Malaysian Global Corporations to arise. Prior to that, in The Ninth Malaysia Plan 2006-2010, greater emphasis has been placed on promoting investment in new areas of 
growth as well as reinforcing innovation capability to augment productivity and competitiveness.

\section{Theory Development on Innovation and Resource Based View (RBV)}

Theory on innovation originates from the theory of economics by Joseph Schumpeter who considered being the founding father of the theory of innovation dynamics. He suggested innovations to be imperative for economic growth, commercial profit, and thus public wealth (Schumpeter, 1934). The definition of innovation as new production functions by Schumpeter (1939) was considered as the future standards of performance used by decision makers in the economic system. Schumpeter (1934) also found that entry tended to be easy for firms with new technology to exploit and emphasized the role of new firms as drivers for innovation. Concerning the matter of innovation as a factor for the company's survival, there are recent strategy namely Blue Ocean Strategy (BOS) or so called reconstructionist strategy (Kim \& Mauborgne, 2007). This strategy was inspired by Schumpeter Creative Destruction theory. The backbone of reconstructionist strategy is 'value innovation'. In this strategy, the innovation (in product, service, or delivery) must raise and create value for the market

Firm's performance also was based on its competencies which have been explained by RBV theory. Superior performance usually base on developing a competitively distinct set of resources and deploying them in a well conceived strategy (Collis \& Montgomery, 1994). Indeed, strategists who embrace the RBV also point out that competitive advantage comes from aligning skills, motives and etc. with organizational systems, structures, and processes that achieve capabilities at the organizational level (Teece et al., 1997). The RBV highlights the firm as a unique collection of resources (Barney, 1986, 1991; Wernerfelt, 1984), but the theory emphasizes that not all these resources possess the potential to provide the firm with a sustained competitive advantage (Clulow, 2007).
When referring to the RBV, most researchers focuses in strategic context, presenting resources and capabilities as essential to gaining a sustained competitive advantage and superior performance (Ferreira \& Azevedo, 2007). The present study will represent the function of entrepreneurship in RBV by highlighting the importance of EO as human resource capabilities. Concerning few theories contributes to the RBV development, the following table 4 highlights the historical view of the underpinning theory and it contribution to RBV.

Integration among the three theories (Schumpeterian, Penroses and RBV) initiates the importance of firm's internal resources as firm's capabilities subject to their uniqueness and their ability to create competitive advantage to the firm

\section{Malaysia SMEs and Product Innovation Performance (PIP)}

PIP has been defined as the economic financial and non-financial outcomes of the firm's product innovation efforts (Cooper 1984; Cooper et al. 1987; Gemunden et al. 1992; Hise et al. 1990; Hollenstein 1996). The relationship between SME's resources and PIP also has been found less documented. Yet, there has been significant interest in product innovativeness in Malaysia in recent years. Even so, the innovativeness of a new product and SME innovation capability is important to present opportunities for SMEs in terms of growth and expansion into new areas as well as allow SMEs to gain competitive advantage.

Malaysia SMEs should be creative and innovative and having effort in producing futuristic product such as healthy food and yogurt rather than other common product to compete in domestic market (How 2008). In global and dynamic competitive environment, innovation is becoming more relevant, mainly as a result of three major trends: intense international competition, fragmented and demanding markets, and diverse and rapidly changing technologies 
(MDIC 2005; Wheelwright et al. 1992). On the other hand, successful innovation is a complex task for SMEs that do not have technological know-how in R\&D activities (Avermaete et al. 2003).

Table 4: The Historical View of the Underpinning Theory and it Contribution to RBV and Entrepreneurship.

\begin{tabular}{|c|c|}
\hline Author & Contribution to RBV \\
\hline $\begin{array}{l}\text { (Barney, 1991; } \\
\text { Rumelt, 1987; } \\
\text { Wernerfelt, } \\
\text { 1984) }\end{array}$ & $\begin{array}{l}\text { Suggests that to be sources of competitive advantage, resources must be } \\
\text { valuable, rare, inimitable and non-substitutable. } \\
\text { Individual resources as unit of analysis. } \\
\text { Focuses on state (equilibrium) where firms earned sustained competitive } \\
\text { advantage. } \\
\text { A strategic resource to one firm is also a strategic resource to another firm. } \\
\text { Usually no distinction between resources and their services. }\end{array}$ \\
\hline $\begin{array}{l}\text { (Nelson \& } \\
\text { Winter, 1982; } \\
\text { Schumpeter, } \\
1934,1942 \text { ) }\end{array}$ & $\begin{array}{l}\text { Technological innovation and "creative destruction" basis of competitive } \\
\text { advantage. } \\
\text { Managerial action and entrepreneurialism influence firm success rather } \\
\text { than market power or industry structure. } \\
\text { Firm view as bundle of resources and hierarchies of activities governed by } \\
\text { routines and rules. }\end{array}$ \\
\hline (Penrose, 1959) & $\begin{array}{l}\text { Firm as bundle of resources } \\
\text { Firm's growth is based on the effective use of resources and limited by } \\
\text { managerial resources. } \\
\text { Entrepreneurship exercised by team, emphasizes alertness as well as } \\
\text { judgment. } \\
\text { Services rather than resources are stressed. }\end{array}$ \\
\hline
\end{tabular}

SMEs need to keep up with creativity and innovation activity in order to sustain in the competitive business environment. Business that offer products that are adapted to the needs and wants of target customers and that market them faster and more efficiently than their competitors are in a better position to create a sustainable competitive advantage (Amit et al. 1993; Calantone et al. 1995; Prahalad et al. 1990). Otherwise, their products will be copied by competitors in less than one year (Slater 1996). Research on successful new product innovations suggests that the most important success factor is developing a product that provides unique benefits and superior value to the customer (Cooper 1999).

In term of SME's performance indicators, innovation surveys carried out by many countries around the world including Malaysia, follow general guidelines set out by OECD publication or Oslo Manual (OECD 2005). However, such guidelines or indicators mostly focused on financial 
indicators such as gross domestic expenditure on R\&D, business enterprise expenditures, technology balance of payments, profitability, market share etc., but lack of information on non-financial indicators that indicate performance in term of product innovation, SME's competitive advantage, business operation such as availability of information technology and communication, product development time, technological breakthrough, product quality etc. Whereas, the non-financial indicators is helpful to understand the performance of organization such as SMEs (Palenberg et al. 2006). Prior to that, the current research will include both financial and nonfinancial indicators as the measurement for the PIP.

\section{SME's Resources and Product Innovation Performance (PIP)}

Resources can be defined as the productive assets of firms, the means through which activities are accomplished (Mathews 2006) and in the same manner it also has been defined as stocks of available factors (knowledge, physical assets, human capital, and other tangible and intangible) that are owned or controlled by the firm, which are converted into final products or services efficiently/effectively (Amit et al. 1993; Capron et al. 1999). Although SMEs have limited resources, some of them are unique compared to their competitors that enable them to create value products to consumers (Day et al. 1988).

Generally, resources can be categorized as tangible and intangible entities. These entities are all the object of entrepreneurial attention that can be acquired and take their place as assets on the company's balance sheet (Mathews 2006). Tangible resources includes capital, access to capital and location etc. and intangible resources consist of knowledge, skills and reputation, EO etc. (Runyan et al. 2006). It is much easier to protect tangible resources and property such as physical and financial assets in a more concrete form compared to intangibles where many factors could make them flow out of the company (Hurmelinna-Laukkanen et al. 1997).
The first published papers in entrepreneurship identifies five types of resources in the context of resource base view (RBV) that are human, social, physical, organizational and financial resources (Greene et al. 1997). Technological resources have been identified in subsequent research as an important dimension for national economic development efforts (Venkataraman 2004). Recently, firm's resources has been categorized in six strategic resources namely physical, reputational, organizational, financial, human//intellectual and technological.

Previous literature on RBV frequently focused on resources as a stable concept that can be identified at a point in time and will endure over time (Dunford et al. 2003). As Casson (2004) points out, RBV is focusing on the importance of human resources, as reflected in competencies and capabilities to the performance of the firm (Teece et al. 1997). Resources may be required in a simple state and combined together by the firm in distinctive combinations that are certainly not easily traded (Mathews 2006). The recombination of resources, activities and linking routines within the firm is the implementation of the strategic choice and it leads to a new set of activities, new sources of revenue and a new business model for the firm (Mathews 2006). The previous listed activities can be categorized as innovation. However, even though a company may be working on an innovation, this does not necessarily mean that a successful product will result (Aboulnasr et al. 2008).

In addition, it appears from the previous literature that intangible resources are in general drivers to firm's success (Amit et al. 1993; Barney 1991; Conner 2002; Michalisin et al. 1997). The present study will identify whether there are similar effects hold for Malaysia SMEs, but in the context of product innovation performance (PIP). Exploring such relationships will enrich understanding on the importance of SME resources in explaining PIP.

\section{Research Methodology}


The list of respondents was based on the SME info Directory by Bank Negara Malaysia. Fifty (50) individuals were selected randomly to take a survey. They were including the business owners and managers who work in various sizes of manufacturing firms, which comprises nine industrial sectors. A number of thirtyseven (37) responses were received. Out of that, they were nine firms with no innovations activities and the remaining amounts of four (4) were non-replied. Firms with no innovation have been detected from the filter question provided in the questionnaire. The study used the questionnaire to measure the PIP, an adaptation of the previous works i.e. Heidt (2008), Alegre et al. (2006) and Weerawardena (2001), and RBV by Galbreath (2004). These additional items have been developed based on the literature review on past studies. Additional questions on innovation on financial performance have been added for PIP part followed by few additional questions on EO for RBV.

\section{Results and Discussions}

Frequency analyses were obtained for all the firms' data and classification variables. The summary of the analysis are shown in Table 5:

\section{Table 5: Summary of Frequency Distributions}

\begin{tabular}{|c|c|c|}
\hline No & Profile of Respondents & Valid Percent (\%) \\
\hline 1 & $\begin{array}{l}\text { Firm's age. } \\
\text { - } \quad 0-5 \text { years (young) } \\
\text { - } \quad 6-10 \text { years (intermediate) } \\
\text { - } \quad \text { More than } 10 \text { years (old/established) } \\
\end{array}$ & $\begin{array}{c}16.2 \\
5.4 \\
78.4 \\
\end{array}$ \\
\hline 2 & $\begin{array}{ll}\text { Company size in terms of annual sales turnover. } \\
\text { - } \text { Micro } \\
\text { - Small } \\
\text { - } \text { Medium } \\
\text { - Large } \\
\end{array}$ & $\begin{array}{c}2.7 \\
10.8 \\
21.6 \\
64.9 \\
\end{array}$ \\
\hline 3 & $\begin{array}{l}\text { Company size in terms of full time employees. } \\
\text { - Micro } \\
\text { - Small } \\
\text { - } \text { Medium } \\
\text { - } \quad \text { Large } \\
\end{array}$ & $\begin{array}{c}2.7 \\
8.1 \\
16.2 \\
73.0\end{array}$ \\
\hline 4 & $\begin{array}{l}\text { Industry types. } \\
\text { - } \text { Electrical and electronic } \\
\text { - } \text { Machine and equipment } \\
\text { - } \text { Pood and beverage } \\
\text { - Rubber products } \\
\text { - Textiles and apparel } \\
\text { - Transport and equipment } \\
\text { - } \text { Basic metal product } \\
\text { - Others }\end{array}$ & $\begin{array}{c}59.5 \\
2.7 \\
10.8 \\
2.7 \\
5.4 \\
2.7 \\
2.7 \\
2.7 \\
10.8\end{array}$ \\
\hline 5 & Firms with R\&D Department. & 83.8 \\
\hline 6 & Firms with no R\&D Department. & 16.2 \\
\hline 7 & Firms with product innovation expertise. & 91.9 \\
\hline 8 & Firms with no product innovation expertise & 8.1 \\
\hline
\end{tabular}


In the survey, PIP was measured using 10 items with two dimensions (financial and non-financial) which has been adapted and modified from previous research (use fivepoint likert scale, ranging from 1 = very low achievement to $5=$ very high achievement). A reliability analysis of the 10 items was undertaken and strong. Cronbach's alpha coefficients of 0.931 emerge for the variables. Overall, there are high achievements in PIP as in the following descriptive statistics in table 6 :

Table 6: Descriptive Statistics for Product Innovation Performance (PIP)

\begin{tabular}{|l|r|r|}
\hline & Mean & \multicolumn{1}{|c|}{ Std. Dev. } \\
\hline regularly of change of PI & 3.84 & 1.093 \\
new product introduction & 3.57 & 1.068 \\
PI technically superior & 3.95 & .880 \\
Technological b/through & 3.92 & .829 \\
market response & 4.08 & .862 \\
Quality & 4.05 & .815 \\
PI introduction time & 3.78 & .917 \\
Profitability & 3.89 & .843 \\
success in gaining market share & 3.84 & .958 \\
improved sales growth & 3.76 & .863 \\
\hline
\end{tabular}

1 = very low achievement in PIP

2 = low achievement in PIP

$3=$ average achievement in PIP

$4=$ high achievement in PIP

5 = very high achievement in PIP

Firm's resources variables was measured using 22 items in six dimension: Physical, financial, human intellectual, organizational, reputational and technological (using five-point likert scale, ranging from 1 = comparatively very low impact on PIP to 5 = comparatively very high impact on PIP).
A reliability analysis of the 22 items was undertaken and strong. Cronbach's alpha coefficients of 0.958 emerge for the variables. Overall, as stated in table 7 , firm's resources given high impact on firm's PIP, whereby buildings given the lowest impact and product reputation given the highest impact on PIP compared to other factors.

Table 7: Descriptive Statistics for Firm's Resources 


\begin{tabular}{|l|r|r|}
\hline & Mean & Std. Dev. \\
\hline Buildings & 3.57 & 1.068 \\
location of buildings & 3.76 & 1.065 \\
physical structure & 3.68 & 1.107 \\
Machineries & 3.97 & .986 \\
financial capital & 3.86 & 1.110 \\
financial investment & 3.84 & .986 \\
cash from operation & 3.73 & 1.071 \\
E0-innovativeness1 & 4.05 & .911 \\
E0-innovativeness2 & 4.11 & .809 \\
E0-proactiveness1 & 3.86 & 1.004 \\
E0-proactiveness2 & 4.19 & .811 \\
E0-risk seeking1 & 3.81 & .908 \\
E0-risk seeking2 & 3.73 & .990 \\
company's reputation & 4.16 & .764 \\
customer service reputation & 4.14 & .713 \\
product reputation & 4.24 & .683 \\
organizational structure & 3.95 & .911 \\
organizational culture & 3.97 & .928 \\
organizational policies & 3.92 & .894 \\
held in secret technology & 4.00 & .913 \\
new/improved product design & 3.95 & .911 \\
unique technological know how & 4.05 & .970 \\
\hline
\end{tabular}

$1=$ comparatively very low impact on PIP

2 = comparatively low impact on PIP

3 = comparatively average impact on PIP

4 = comparatively high impact on PIP

$5=$ comparatively very high impact on PIP

The following table 8 shows that SMEs resources explain $94.1 \%$ of the variance ( $R$ Square) in PIP, which is highly significant, as indicated by the F-value of 27.224 in table 9.

\section{Table 8: Model Summary for SME resources}

\begin{tabular}{|l|r|r|r|}
\hline Model & R & R Square & \multicolumn{2}{c|}{ Adjusted R Square } \\
\hline 1 & $.989(\mathrm{a})$ & .977 & .941 \\
\hline
\end{tabular}

Table 9: ANOVA

\begin{tabular}{|c|c|c|}
\hline & $\mathrm{F}$ & Sig. \\
\hline $\begin{array}{l}1 \text { Regression } \\
\text { Residual } \\
\text { Total }\end{array}$ & 27.224 & $.000(a)$ \\
\hline
\end{tabular}

An examination of t-values in table 10 indicates that cash from operation, 
proactiveness (EO), product reputation and physical structure contributes to the

prediction of PIP.

Table 10: Coefficients

\begin{tabular}{|c|c|c|}
\hline Firm's Resources & t-value & Sig. \\
\hline \multirow{6}{*}{$\begin{array}{l}\text { 1) Cash from operation } \\
\text { 2) E0- proactiveness } \\
\text { 3) Product reputation } \\
\text { 4) Physical structure }\end{array}$} & 3.72 & 0.002 \\
\hline & & \\
\hline & 3.70 & 0.002 \\
\hline & & \\
\hline & 3.03 & 0.009 \\
\hline & 2.20 & 0.045 \\
\hline
\end{tabular}

Cash from operation (cash in hand/at bank) is the important element of good business strategy to pursue with new product innovation and enhancing PIP. Good operational cash will support their innovation performance and being an opportunity to further develop their products. Many SMEs have great business ideas and this is reflected in their products and services, however, many businesses fail because they could not maintain their cash very well and this is often the barriers for Malaysia SMEs to identify and pursue new market opportunities.

In term of proactiveness (EO) as the intangible resources, Covin et al. (1989; 1991) suggested that proactive firms compete aggressively with other firms. Proactiveness suggests a forwardlooking perspective characteristic of a marketplace leader that has the foresight to act in anticipation of future demand. Proactiveness also is shaping the environment by introducing new products and technologies. In addition, proactive entrepreneurial personality will lead to proactive firms which can differentiate themselves from their competitors by changing their production methods and products to be more innovative.

Other intangible resources, the product reputations, even though they are difficult to acquire and develop or replicate by others, when they mixes up with innovation activities, they will create excellent product innovation performance as reputation lies in customer's mind. Good reputation creates opportunities for Malaysia manufacturing companies to be more innovative. The performance of product innovation in Malaysia manufacturing companies can be identified through the positive market response and the improvement in the product design itself.

In addition, a manufacturing firm must consider proximity to suppliers and customers, as well as local taxes and regulations. This kind of proximity is very practical for ease of communication among the previous listed parties. Good communication among the parties will create good reputation especially for the manufacturing firms which offers products or services. As mentioned before, product reputation will then be the starting point for the firm to add more values to the product in order to create customer awareness and maintaining networking with it supplier, financial institutions, government and other related parties.

The above findings also are in line with the RBV point of view that focuses on intangible resources as the main drivers for firm's performance which comprise the element of product innovation as one the performance indicators. Firm's performance can be measured by looking at the differences between firm's profitability and the average profitability of the industry (Villalonga, 2004). The present paper focusing on firm's specific performance that is PIP. Malaysia manufacturing firm have been found gained high profitability from its product innovation. It can be concluded that their achievement in innovation are quite high especially through it intangible resources, the product reputation. 
Physical structure also contributes as the predictor for firms PIP. Physical structure such as the strategic location of the building with a proper warehouse, attractive showrooms etc. will affect the performance of product innovation. The location of the building is very important to ensure there are adequate supply of labour and raw materials (resources) for production process. As mentioned earlier, resources are the ultimate tools for used by the firms to improved profitability, roductivity and innovation. (Montana \& Charnov, 2000).

Surprisingly, technological resources have been found not a good predictor for firm's PIP. Even though technological resources which consist of advanced technology and unique technological know-how are mainly essential for SMEs as they frequently compete through new product development, technological may not be the source of sustainable performance if it does not couple with other unique capabilities of the firm. For example, it was suggested that companies need intelligence gathering capabilities to keep up with technology development including both formal processes and information systems (Tyler 2001).

On the other hand, since the study seeks to examine the relationship between SME resources and PIP, the bivariate correlation is conducted. Thus the output of bivariate correlation confirms that a significant positive relationship exists between tangible resources and PIP ( $\mathrm{r}=0.524, \mathrm{p}<$ 0.05), and intangible resources and PIP ( $r$ $=0.713, \mathrm{p}<0.05)$ respectively (Table 11 and 12).

Table 11: Bivariate Correlation Tangible Resources - PIP

\begin{tabular}{|ll|r|r|}
\hline & & $\begin{array}{c}\text { sum of product } \\
\text { innovation performance }\end{array}$ & tangible resources \\
\hline $\begin{array}{l}\text { sum of product } \\
\text { innovation } \\
\text { performance }\end{array}$ & Pearson Correlation & 1 & $.524\left(^{* *}\right)$ \\
& Sig. (1-tailed) & & .000 \\
& $\mathrm{~N}$ & 108 & 108 \\
tangible & Pearson Correlation \\
resources & Sig. (1-tailed) & $.524\left(^{* *}\right)$ & 1 \\
& $\mathrm{~N}$ & .000 & 108 \\
\hline
\end{tabular}

** Correlation is significant at the 0.01 level (1-tailed).

Table 5.10: Bivariate Correlation Intangible Resources - PIP

\begin{tabular}{|ll|r|r|}
\hline & & \multicolumn{1}{|c|}{$\begin{array}{c}\text { sum of product } \\
\text { innovation performance }\end{array}$} & intangible resources \\
\hline $\begin{array}{l}\text { sum of product } \\
\text { innovation } \\
\text { performance }\end{array}$ & Pearson Correlation & 1 & $.713\left(^{* *}\right)$ \\
& Sig. (1-tailed) & 108 & .000 \\
& $\mathrm{~N}$ & $.713\left(^{* *}\right)$ & 108 \\
intangible & Pearson Correlation & .000 & 1 \\
resources & Sig. (1-tailed) & 108 & 108 \\
& $\mathrm{~N}$ & & \\
& & & \\
\end{tabular}

** Correlation is significant at the 0.01 level (1-tailed). 
The findings show that in order to bringing up PIP, SMEs should focus on the utilization of tangible resources (i.e. high utilization of fixed assets; low cost plant location; and access to adequate supplies and labor) and intangible resources including low cost production efficiency; quality of manufacturer; high labor productivity; low cost product design and engineering; and flexibility in manufacturing. In terms of information technology, the intangible resources, firms are recommended to perfect the technology and adopt it quickly in order to improve product quality and to develop attractive performance features (Kotler, 1984; Porter, 1980) since successful product innovation opens up an avenue for competing besides beating rival's prices and being difficult for them to imitate.

Finally, most of the companies in the test study are more than 10 years since incorporation. Established company is well known in their reputation and also having opportunities gaining more loans and financial assistance for their product innovation. Out of fifty companies, nine of it was non innovative firms. The reason why there are non innovative are because of they are lack of financial assistance and technology. This finding is supported by Kaufmann and Todtling (2002) who discover that besides confronted with financial and technology coanstraints, non innovative SMEs also having manpower bottlenecks in terms of few of qualified personell in product innovation.

\section{Limitations and Future Direction of the Study}

Several limitations of this research should be mentioned. First, the study is mainly restricted to the context of study; therefore, it will be problematic to generalize its findings to other sectors. Also, as the ground of this study in PIP is quite new, the data must be interpreted cautiously. Finally, future research are encourage using qualitative methods focusing in one industrial sector/case study to a better understanding of the nature of product innovation and firm resources.

\section{Conclusion}

In summary, the overall findings are in line with the RBV point of view that focuses on intangible resources as the main drivers for firm's performance. In term of EO as the intangible resources, Covin et al. (1989; 1991) suggested that firms with proactive EO compete aggressively with other firms. Nevertheless, the innovation activities which embedded with other intangible resources, such as the product reputations create excellent PIP. As for tangible resources, cash from operation is the important element of good business strategy to pursue with new product innovation and enhancing PIP. Physical structure, also contributes as the tangible predictor for firms PIP. However, technological resources have been found not a good predictor for firm's PIP. Meanwhile, while looking at the relationship between SME resources and PIP, the output of bivariate correlation shows a significant positive relationship between SME resources and PIP.

\section{References}

Aboulnasr, K., Narasimhan, O., Blair, E., and Chandy, R. (2008), 'Competitive Response to Radical Product Innovations,' Journal of Marketing (72) (5), pp 94-110.

Alegre, J., Lapiedra, R., and Chiva, R. (2006), 'A Measurement Scale for Product Innovation Performance,' European Journal of Innovation Management (9) (4), pp 333-346.

Amit, R., and Schoemaker, P. (1993), 'Strategic Assets and Organizational Rent,' Strategic Management Journal (14) (1), pp 33-46.

Avermaete, Viaene, J., Morgan, E.J., and Crawford, N. (2003), 'Determinants of Innovation in Small Food Firms, ' European Journal of Innovation Management (6) (1), pp 8-17.

Barney "Strategic Factor Markets: Expectation, Luck and Business Strategy 
(1986), 'Management Science,' (32) (10), pp 1231-1241.

Barney "Firm Resources and Sustained Competitive Advantage (1991), ' Journal of Management,' (17) (1), pp 99-120.

BERNAMA (2008), 'Smidec to be central of Coordinating Agency, says Abdullah,' in: Bernama.Com, Kuala Lumpur.

BNM (2005), 'Definitions for small and medium enterprise in Malaysia (Approved for adoption by National SME Development Council on June 2005),' Bank Negara Malaysia, pp. 1-7.

Calantone, R.J., Vickery, S.K., and Dröge, C. (1995), 'Business Performance and Strategic New Product Development Activities: An Empirical Investigation,' Journal of Product Innovation Management (12), pp 214-223.

Capron, L., and Hulland, J. (1999), 'Redeployment of Brands, Sales forces and General Marketing Management Expertise Following Horizontal Acquisitions: A Resource Based View," Journal of Marketing (63) (4), pp 41-54.

Casson, M. (2004), 'Entrepreneurship and The Theory of The Firm,' ATOM Workshop, Journal of Economic Behavior and Organization, Paris.

Clulow, V. (2007), 'The Resource Basedview and Value: The Customer-Based View of the Firm, ' Journal of European Industrial Training (31) (1), pp 19-35.

Conner, T. (2002), 'The Resouce-based View of Strategy and Its Value to Practicing Managers," Strategic Change (11), pp 307316.

Cooper (1984), 'The Strategy-performance Link in Product Innovation, ' $R \& D$ Management (14) (4), pp 247-267.

Cooper (1999), 'The Invisible Success Factors in Product Innovation,' Journal of Product Innovation Management (16) (2), pp 115-133.
Cooper, and Kleinschmidt, E.J. (1987), 'Success Factors in Product Innovation,' Industrial Marketing Management (16) (3), pp 215-223.

Covin, J.G., and Slevin, D.P. (1989), 'Strategic Management of Small Firms in Hostile and Benign Environments," Strategic Management Journal (10), pp 7587.

Covin, J.G., and Slevin, D.P. (1991), 'A Conceptual Model of Entrepreneurship as Firm Behavior. ," Entrepreneurship Theory and Practice (16) (1), pp 7-24.

Damodaran, R. (2008), 'Malaysia not losing its invesment appeal,' New Straits Times, p. 41.

Day, G.S., and Wensley, R. (1998), 'Assessing Advantage: A Framework for Diagnosing Competitive Superiority,' Journal of Marketing (52) (4l), pp 1-20.

Dunford, B.B., Snell, S.A., and Wright, P.M. (2003), 'Human resources and the resource based view of the Firm,' Center for Advanced of Human Resource Studies, School of Industrial and Labour Relations, Cornell University, pp. 1-35.

Ferreira, J., and Azevedo, S. (2007), 'Entrepreneurial Orientation as a Main Resource and Capability on Small Firm's Growth,' in: Munich Personal RePEc Archive, pp. 1-20.

Galbreath (2004), 'Determinants of Firm Success: A Resource-based Analysis," in: Graduate School of Business, Curtin University of Technology, Curtin, p. 260.

Gemunden, H.G., and Heydebreck, P. (1992), 'Technological Interweavement: A Means of Achieving Innovation Success,' R\&D Management (22) (4), pp 359-376.

Greene, P.G., and Brown, T.E. (1997), 'Resource Needs and The Dynamic Capitalism Typology," Journal of Business Venturing (12), pp 161-173.

Hashim, M.K. (2004), 'Relative Strengths and Weaknesses of SMEs in Malaysia: A 
Review of Literature. The Asian Economic Review, April 2004," The Asian Economic Review.

Heidt, T.v.d. (2008), 'Developing and testing model of cooperative interorganizational relationships (IORs) in product innovation in an Australian manufacturing context: A multistakeholder perspective,' in: School of Commerce and Management, Sourthern Cross University, Lismore, pp. 1-390.

Hise, R.T., and O'Neal, L. (1990), 'Marketing/R\&D Interaction in New Product Development Implications for New Product Success Rates,' Journal of Product Innovation Management (7) (2), pp 142155.

Hitt, M.A., Ireland, R.D., Camp, S.M., and Sexton, D.L. (2001), 'Strategic Entrepreneurship: Entrepreneurial Strategies for Wealth Creation,' Strategic Management Journal (22) (6), pp 479-492.

Hollenstein, H. (1996), 'A Composite Indicator of a Firm's Innovativeness: An Analytical Analysis Based on Survey Data for Swiss Manufacturing," Research Policy (25), pp 633-645.

How, A.Y. (2008), 'Produk IKS perlu patuh spesifikasi," in: Utusan Malaysia Online, Subang Jaya.

Hurmelinna-Laukkanen, P., and Puumalainen, K. (1997), 'Formation of The Appropriability Regime: Strategic and Practical Considerations," in: Innovation: Management, Policy, \& Practice.

Kam, R. (2008), 'Local SMEs told to move up value chain," in: The Star Online, Petaling Jaya.

Lunati, M., Dembinski, P.H., and Farinelli, F. (2004), 'Enhancing the Role of SMEs in Global Value ChainsTokyo,' Organization of Economic Cooperation Development, Tokyo, pp. 2-86.

Mathews, J.A. (2006), 'Resource and activities are two sides of the same coin: Duality of the activities and resource-based views of strategic management,' Conference on Strategic Management Copenhagen.

MDIC (2005), Catalyst for Building Competitiveness, M.B.a.P.D. Centre (ed.), Malaysia Design Innovation Centre, Selangor Malaysia.

Michalisin, M.D., Smith, R.D., and Kline, D.M. (1997), 'In Search of Strategic Assets,' The International Journal of Organizational Analysis (5), pp 360-387.

MIDA (2007), 'Malaysian Industrial Development Authority,' MIDA.

NSDC (2006), 'SME Annual Report 2006,' National Small Medium Enterprise Development Corporation, Kuala Lumpur.

NST (2008), 'Plastic makers say sector will meet projected growth,' in: New Straits Time, p. 39.

OECD (2005), 'Oslo Manual'.

Palenberg, M., Reinicke, W., and Witte, J.M. (2006), 'Trends In Non-financial Reporting,' D.o.T. United Nations Environment Programme, Industry and and E. (DTIE) (eds.), Global Public Policy Institute, pp. 1-50.

Prahalad, C.K., and Hamel, G. (1990), "The Core Competence of the Corporation," Harvard Business Review (68:3), pp 79-91.

Runyan, R., Huddleston, P., and Swinney, J. (2006), 'Enrepreneurial Orientation and Social Capital as Small Firm Strategies: A Study of Gender Differences From a Resource-Based View," Entrepreneurship Management (2), pp 455-477.

Saleh, and Ndubisi, N.O. (2006), 'An Evaluation of SME Development in Malaysia," International Review of Business Research Papers (2) (1),pp 1-14.

Slater, S.F. (1996), 'The Challenge of Sustaining Competitive Advantage,' Industrial Marketing Management (25), pp 79-86. 
SMIBD (2008), 'Overview of SMIs/SMEs,' Small Medium Enterprise Business Development, p. 3.

Teece, D.J., Pisano, G., and Shuen, A. (1997), 'Dynamic Capabilities and Strategic Management,' Strategic Management Journal (18) (7), pp 509-533.

Tyler, B.B. (2001), 'The Complimentary of Cooperative and Technological Competencies: A Resource Based Perspective,' Journal of Engineering Technology Management (18), pp 1-27.

UNDP (2007), 'Malaysia Small and Medium Enterprises,' United Nations Development Programme, Kuala Lumpur, pp. 1-20.

Venkataraman, S. (2004), 'Regional Transformation Through Technological
Entrepreneurship," Journal of Business Venturing (19) (1), pp 153-167.

Weerawardena, J., and Coote, L. (2001), 'An Empirical Investigation into Entrepreneurship and Organizational Innovation-based Competitive Strategy,' Journal of Research in Marketing \& Entrepreneurship (3) (1), pp 51-70.

Wernerfelt, B. (1984), 'A Resource-based View of The Firm," Strategic Management Journal (5), pp 171-180.

Wheelwright, S.C., and Clark, K.B. (1992), 'Revolutionizing product development Quantum leaps in speed, efficiency, and quality,' The Free Press, New York, NY. 